\title{
New Hope for Cancer Immunotherapy: Viral Based Cancer Vaccines
}

\author{
Nemat Khansari* \\ Department of Immunology, Tehran University of Medical Sciences, Tehran, Iran \\ *Corresponding author: Nemat Khansari, Department of Immunology, Tehran University of Medical Sciences, Tehran, Iran \\ Submission: April 14, 2018; Published: April 25, 2018
}

\section{Opinion}

Cancer cases are increasing every year in all communities all over the world. Among many causes, environmental factors are considered highest cause of this increase. Socioeconomic impacts of this event lead scientists to expedite research toward finding new therapeutic modalities for treatment of this deadly disease.

During past 50 years many new treatment approaches have been developed. Most of the new modalities are based immunotherapy by either potentiating system nonspecifically or by potentiating specific cytotoxic lymphocytes to destroy tumor cells. Among many therapeutic vaccines tried, dendritic cell-based cancer vaccines have gotten more attention since last decade [1]. Even though there has been some success in a few cancer cases but total remission in a lot of cases have not been achieved [2]. In 1964, Wheelock and Dingle reported that repeated injection of Newcastle Disease Virus (NDV) to a patient suffering from acute lymphoblastic leukemia cured patient [3]. Later on, Csatary reported regression od metastatic colon cancer in a farmer patient following NVD outbreak in chicken farms [4].

NDV is an Avian paramyxovirus type 1 belonging to the genus Avulavirus in the family of the Paramixoviridae. This virus affects different avian species worldwide causing Newcastle disease. NDV is endemic in many countries causing an acute respiratory disease in domestic poultry, but depression, nervous manifestations, or diarrheas may be the predominant clinical symptoms [5]. Severity of the disease depends on the virulence of the infecting virus and the host susceptibility. Although NDV does not poses hazard to human health but can cause a transient conjunctivitis and mild flulike symptoms.

After report of Csatary in 1971, scientists showed great interest to use mesogenic and lentogenic strains of NVD as a virotherapy in murine tumor model and even in cancer patients successfully [6]. The advantage this virus is that it selectively replicates in human cancer cells but not in normal human cells. In early 1990s, Reichard et al. [7] reported that NDV strain 73-T replicates in and kills human tumor cells, including fibrosarcoma, osteosarcoma, cervical carcinoma, bladder carcinoma, neuroblastoma , both in vitro and, in vivo. Walter et al. [7] reported while pancreatic tumor cell lines were killed by low dose of the NDV, normal cells were killed by very high doses of the NDV [7].

NDV virotherapy has been used in clinical trials four different forms: vaccination with free infectious NDV particles, vaccination with lysate from NDV-infected tumor cells, vaccination with intact irradiated autologous tumor cells infected with NDV, and vaccination with dendritic cells pulsed with lysates from NDVinfected autologous tumor cells. Our experiences show that efficacy of NDV-infected autologous tumor cell vaccines was higher than the other kind of NDV-based vaccines [8]. Currently, we are working on application of different low virulent virus infected autologous tumor cell vaccines and our preliminary results in murine model show very impressive results.

\section{References}

1. Prince AM, Ginsberg HS (1957) Studies on cytotoxic effect of Newcastle disease virus (NDV) on Ehrlich ascites tumor cells. I. Characterization of the virus-cell interaction. J Immunol 79(2): 94-106.

2. Schirrmacher V (2015) Oncolytic Newcastle disease virus as a prospective anti-cancer therapy. A biologic agent with potential to break therapy resistance. Exp Open Biol Ther 15(12): 1757-1771.

3. Wheelock EF, Dingle JH (1964) Observations on the repeated administration of viruses to a patient with acute leukemia. A preliminary report. N Engl J Med 271: 645-651.

4. Csatary LK (1971) Viruses in the treatment of cancer. Lancet 2: 825.

5. Miller PJ, Koch G (2013) Newcastle disease, other avian paramyxoviruses, and avian metapneumovirus infections; Newcastle disease. In: Swayne Deeic, Gilsson, McDougald LR, Nolan LK, Suarez DL, Nair V (Eds.), Diseases of poultry. $\left(13^{\text {th }}\right.$ edn), Wiley-Blackewell, Hoboken, NJ, USA, pp. 89-138.

6. Alexander DJ (2003) Newcastle disease and other avian Paramyxoviruses infections. In: Saif YM, (Eds.) Iowa State University Press, Ams, USA, pp. 63-99.

7. Reichard KW, Lorence RM, Cascino CJ, Peeples ME, Walter RJ, et al. (1992) Newcastle disease virus selectively kills human tumor cells. J Surg Res 52(5): 448-453.

8. FarashiBonab, S, Khansari N (2017) Virotherapy with Newcastle disease virus for cancer treatment and its efficacy in clinical trials. MOJ Immunol 5(6): 176-181. 
Creative Commons Attribution 4.0 International License

For possible submissions Click Here

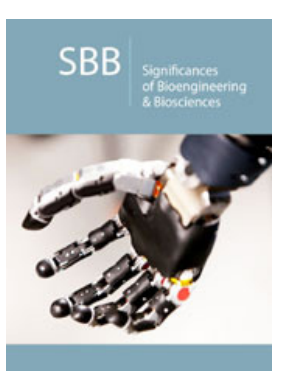

Significances of Bioengineering \& Biosciences

\section{Benefits of Publishing with us}

- High-level peer review and editorial services

- Freely accessible online immediately upon publication

- Authors retain the copyright to their work

- Licensing it under a Creative Commons license

- Visibility through different online platforms 